\title{
JACKSON HOLE WILDLIFE PARK: AN EXPERIMENT TO BRIDGE TOURISM AND CONSERVATION
}

\section{DIANE M. SANDERS $\uparrow$ PUBLIC LANDS HISTORY CENTER COLORADO STATE UNIVERSITY $\downarrow$ FORT COLLINS, CO}

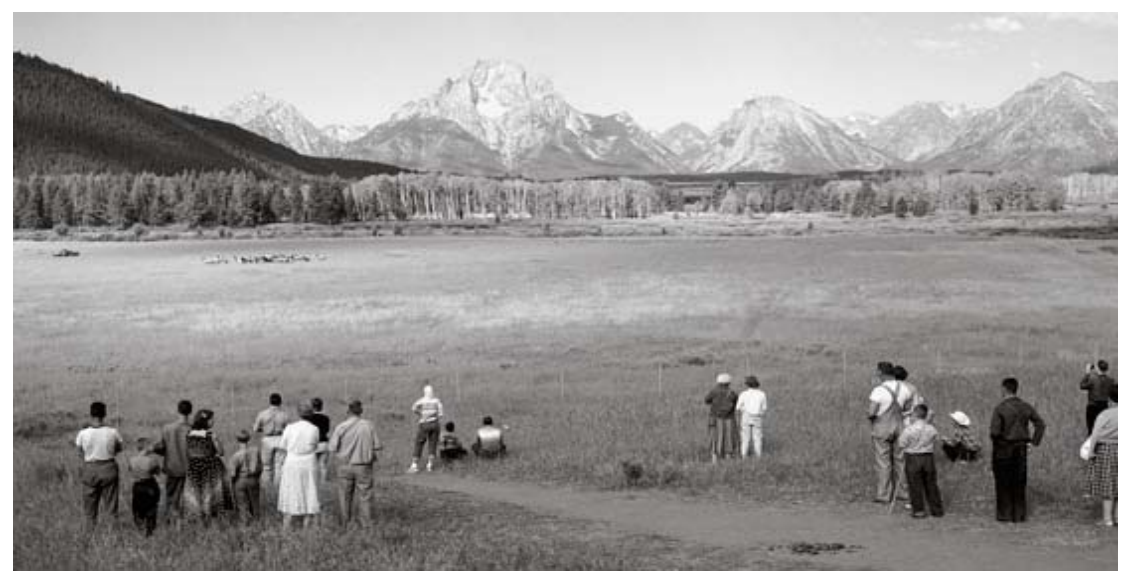

Observing elk in Buffalo Meadow, 1950. Photo courtesy of the National Park Service.

\section{$\uparrow \quad$ INTRODUCTION}

From a vantage point on a rise above the Snake River, the valley below is shrouded in darkness. A faint glow on the eastern horizon heralds the dawn. The only sound comes from the river as water gurgles over rocks and other impediments. As the sky grows brighter, the shadows in the valley begin to take form, revealing numerous small streams that braid through dense thickets of willows and other shrubbery before returning to the main river channel. Small dark shapes dart among the trees and shrubs, filling the air with a variety of birdsongs. As the rising sun gradually illuminates the valley a herd of elk rise, one-by-one, in a distant meadow and begin grazing on the spring grasses. Moments later a cow moose and her calf emerge from behind the willows at the water's edge, scattering the birds. This area, with its mosaic of habitats, teems with wildlife. It is not surprising, then, that this upper part of Jackson Hole became the chosen site for the Jackson Hole Wildlife Park (JHWP) and became the Park's main animal viewing area for tourists and scientists alike.

Anticipating a changing economy at the close of World War II, Wyoming Governor Lester C. Hunt initially conceived the idea of a wildlife museum in Jackson Hole to draw more tourists to the state. That idea quickly morphed into the concept of the JHWP, a facility for the exhibition of the predominant game animals of the West. Without an appropriate tract of land under state control Governor Hunt turned to Laurance S. Rockefeller (Rockefeller), president of Jackson Hole Preserve, Inc. (JHP), which held title to over 33,000 acres of land outside the boundaries of Grand Teton National Park (GTNP) in the upper Snake River Valley of Jackson Hole. The two men 


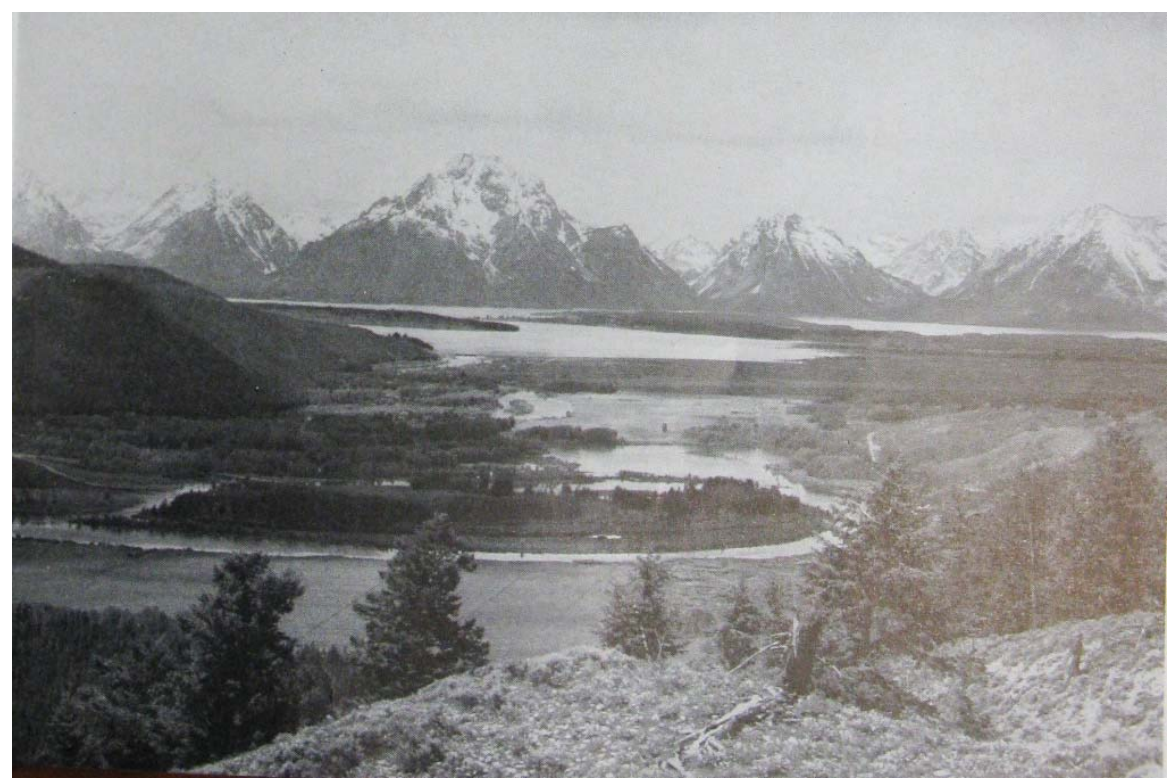

Figure 1. This view, looking west toward Jackson Lake and the Teton Mountains, shows the majority of the JHWP. Buffalo Meadow, the large open area below the rise from where the photograph was taken, was the primary animal viewing area. The original Park headquarters was located in front of the line of trees at the far end of the smaller meadow to the west. Photo acquired from an article published in Animal Kingdom magazine. ${ }^{1}$

shared the belief that commercial development and conservation were not mutually exclusive. They envisioned a wildlife park with an animal viewing area convenient for tourists. As the concept of the park developed they discussed having on-site interpretive guides and printed materials to educate visitors about the animals and the importance of maintaining their habitats to ensure the animals' survival. Early in the process planners also advanced the idea of the wildlife park having the capacity to host a variety of scientists to conduct studies in wildlife life cycles and behavior, and other ecological studies. For support and guidance they enlisted the New York Zoological Society (NYZS), perhaps the world's foremost authority on wildlife conservation at the time. ${ }^{2}$

Many people within the conservation community vehemently opposed the proposed wildlife park. Most conservationists supported tourism development when it did not interfere with the natural activities and movements of the area's animals. Therefore they argued against the unnatural conditions of confining migratory animals such as elk, deer, antelope, and other ungulates within fenced areas. Many spoke passionately about the artificiality of viewing animals in strategically placed pens, regardless of the pen's size, simply for the convenience of tourists. Even the National Park Service (NPS), which remained mute on the project so as not to offend the Rockefellers, had eliminated almost all artificial wildlife viewing areas from the national parks before Hunt proposed the JHWP. Just a year before NPS Director Newton Drury directed Yellowstone to remove the fencing around its bison pastures. Applying the findings of wildlife ecologists and other scientists Drury worked to end the practice of managing national parks as "zoological park[s] or game farm[s]."3

However, many of these same people supported the idea of an area for scientific study. Conservationists, especially wildlife biologists and ecologists, strongly advocated a renewed emphasis on the scientific study of wildlife, something that had diminished during the war years. Conservation could only move forward as the breadth of information about wildlife and their habitats expanded. Yet they also

1 "The Inauguration of the Jackson Hole Wildlife Park," Animal Kingdom: The Magazine of the NYZS, Vol. LI, No. 5, October 1, 1948, Box 5, Series 13, Folder 1, RG5: Jackson Hole Wildlife Park, Grand Teton National Park, Moose, Wyoming (hereafter referred to as RG5 GTNP).

${ }^{2}$ Fabian to Laurance S. Rockefeller (LSR), August 6, 1945, Box 2, Folder 1945, Richard Winger Papers, American Heritage Center (AHC), Laramie, WY (hereafter referred to as Winger Papers); "Big Wildlife Exhibit to Be Set Up," Wyoming Tribune, October 2, 1945, Box 2, Folder 1945, Winger Papers.

${ }^{3}$ Richard West Sellars, Preserving Nature in the National Parks: A History New Haven: Yale University Press, 1997), $156-158$. 
understood the necessity of conducting such research only under natural, unconstrained conditions. They believed that any scientific studies conducted under artificial confinement would produce unusable, false data.

Despite the opposition, the JHWP opened in 1948. Within two years the importance of wildlife and habitat research resulted in the formal establishment of a biological research station within the Park. Very quickly the research station gained priority over the tourist facilities. Early studies contributed greatly to the management of the Jackson Hole elk herd and increased understanding of vegetation degradation and regrowth. Yet visitors to the JWHP did gain an appreciation for animals they otherwise might never have seen except in a traditional zoo enclosure. In that mission, Rockefeller and others viewed the park as a success. Governor Hunt and Rockefeller had correctly foreseen the compatibility of tourism and conservation.

What eluded the men behind the wildlife park was the growing impact of the science of ecology on evolving wildlife management practices. Following the expansion of GTNP, the NPS took over the operation of the JHWP. NPS management policies gradually fell in line with those advocated by Olaus Murie and the other conservationists who had objected to the artificial containment of wild game animals. Funding for the JHWP gradually dwindled, its miles of fencing were allowed to deteriorate. It slowly disappeared into the landscape; but for twenty years it had introduced visitors to some of the most magnificent animals of the West-bison, elk, moose, and antelope. What remains, the lasting legacy of the JHWP, is the Biological Research Station. Now operated by the University of Wyoming in cooperation with the NPS, it hosts scientists from across the country and around the world. Their work continues to advance our understanding about the region's plants and animals, the impacts of climatic change and a host of other topics of pivotal importance to the conservation of our planet and all of its inhabitants.

\section{$\uparrow$ PRECEDENT}

The idea of staged wildlife exhibits was not new or novel. As early as 1894 a private concessioner operated a zoo-type facility in Yellowstone that housed elk, bison, and bighorn sheep as well as a

${ }^{4}$ Alice Wondrak Biel, Do (Not) Feed the Bears: The Fitful History of Wildlife and Tourists in Yellowstone (Lawrence: University of Kansas Press, 2006), 8-11, 18. variety of domestic livestock. Poorly managed, in 1907 Park Superintendent S. B. M. Young ordered the owner to close the complex and release the animals. However, several very popular bear feeding grounds located near Yellowstone's major hotels continued to entertain guests for several decades. When the NPS took over the management of the national parks in 1916, the agency's first director, Stephen Mather, and his assistant Horace M. Albright, who became Yellowstone's superintendent in 1918, enthusiastically endorsed wildlife exhibits. While the initial purpose for the establishment of the nation's parks was to protect unique, majestic landscapes, Mather and Albright knew that visitors placed equal emphasis on observing native wildlife. ${ }^{4}$

Pragmatic men, Mather and Albright understood that Congressional funding for the fledgling new agency would be directly related to the number of tourists who visited the parks. To lure tourists and garner their lasting support for the NPS the men adopted a philosophy of aesthetic conservation. This approach to sustainable development focused on protecting the land and its animals for recreational and sightseeing opportunities versus utilitarian conservation practices that endorsed extractive activities such as hunting, mining and lumbering. Almost immediately the NPS promoted the establishment of zoos and wildlife preserves within the national parks for their entertainment value. To impress upon the public the importance of the national parks, the NPS combined conservation education with the animal exhibits. Park rangers taught onlookers about the animals and their natural habitats. They also informed visitors of the NPS's mission of protecting both the animals and the landscapes for generations to come in an attempt to get the public involved in conservation. ${ }^{5}$

By 1924, under Albright's direction a new staged exhibit, or zoo, opened near the existing buffalo show corral in Mammoth Hot Springs. It displayed a variety of animals caught within Yellowstone's boundaries including black-tailed deer, elk, badgers, a coyote, an aviary, and a pair of black bears. The semitamed animals proved very popular with park visitors who were encouraged to get close to the animals for memorable photo opportunities. Combined with the ongoing bear feeding exhibitions, the ability to observe wildlife at close range developed into a major entertainment experience for park visitors. ${ }^{6}$

\footnotetext{
${ }^{5}$ Ibid., 11-13, 20.

${ }^{6}$ Ibid., 11-16.
} 
Yellowstone was not alone. Other national parks utilized wildlife to lure tourists. Since the caverns hidden underground constituted the main attraction of South Dakota's Wind Cave National Park it drew additional tourists by establishing a game preserve in 1913 as a sanctuary for bison. The NYZS and the American Bison Society donated the preserve's original fourteen animals. The variety of game animals expanded the following year with the introduction of antelope and elk. Western game animals delighted visitors of this prairie environment. At the same time tourists in Rocky Mountain National Park enjoyed close encounters with unusually docile bighorn sheep. $^{7}$

\section{ORIGINS AND CONTROVERSY SURROUNDING THE JHWP}

As the nation began looking forward to the end of World War II during the summer of 1945 Governor Hunt, former Wyoming Governor Leslie Miller and the State Game Commissioner, Lester Bagley, pondered ways to contribute to the State's economic development by bolstering tourism. Hunt's initial idea of a wildlife museum quickly expanded into that of a wildlife preserve and exhibition ground. The precedent for such a facility having already been established and proven popular, the challenge they faced was finding a suitable site. They turned to the one family and man known to be dedicated to conservation and who owned an appropriate tract of land, Laurance S. Rockefeller.

The men traveled to Jackson Hole on August 5, 1945 to sell their idea to Harold Fabian, Rockefeller's legal representative in the valley. The meeting lasted through the afternoon and into the evening. The discussion included the need of a sufficiently large enough tract of land to minimize, if not avoid, habitat degradation by the number and variety of animals the complex would house; the need to hide containment fencing to maintain a natural appearance; and possible sources of opposition. Fabian enthusiastically drafted a letter explaining the project to Rockefeller the following day. His letter

7 "Wildlife Management - Creating a Game Preserve," Wind Cave National Park, National Park Service, http://www.nps.gov/wica/parkmgmt/wildlife-managementcreating-a-game-preserve.htm, accessed March 13, 2014; Biel, Do (Not) Feed the Bears, 14.

${ }^{8}$ Fabian to LSR, August 6, 1945, Box 2, Folder 1945, Winger Papers.

${ }^{9}$ Marion Albright Schenk, "One Day on Timbered Island: How the Rockefellers' Visits to Yellowstone Led to also documented the publics' genuine interest in game animals, describing cars stopped along Jackson Hole roadways for hundreds of yards while tourists observed and photographed wild animals in their natural habitats. ${ }^{8}$

Hunt, Miller, and Bagley's decision to pursue Rockefeller was well considered. Laurance first visited Jackson Hole with his father, John D. Rockefeller, Jr. and two of his brothers in 1924. A return trip two years later led to an alliance between his father, already involved in conservation projects throughout the country, and Albright to save Jackson Hole from undue commercialization and to create Grand Teton National Park. ${ }^{9}$ Soon thereafter Mr. Rockefeller founded the Snake River Land Company to begin purchasing private landholdings in the valley with the ultimate goal of donating the land to the federal government for inclusion in the yet to be established park. Within a decade the company held title to over 33,000 acres in Jackson Hole.

In 1941, the Snake River Land Company evolved into JHP whose purpose was to hold and manage the properties. Of all of the Rockefeller children, Laurance most avidly pursued his father's interest in conservation. In 1945, he assumed control of JHP, thereby committing himself to bringing his father's vision of Jackson Hole to fruition. Through JHP he also completed other projects begun by his father while greatly expanding the family's dedication to conservation activities. ${ }^{10}$

Convinced of the merits of the project, Rockefeller swiftly contributed his unqualified support. Less than two months after the initial meeting with Fabian the concept had expanded to include not only economic development based on a new tourist attraction but also the desire to provide for wildlife research. The Wyoming Tribune published an article describing the fundamentals of the proposal, touting its potential to attract thousands of tourists and an "area for scientific study...on a scale unparalleled in the nation." The article revealed that Rockefeller had pledged the needed land, that the wildlife park would be managed by a non-profit entity, and that the New York Zoological Society, "doubtless the outstanding

Grand Teton National Park," in Montana: The Magazine of Western History, Vol. 57, No. 2 (Summer 2007), 28-29, 3233; Nancy Newhall, A Contribution to the Heritage of Every American: The Conservation Activities of John D. Rockefeller, Jr. (New York: Alfred A. Knopf, 1957), 110.

${ }^{10}$ Robert W. Righter, Crucible for Conservation: the Struggle for Grand Teton National Park (Boulder: Colorado Associated University Press, 1982), 130-131. 
organization in live animal conservation and management in the world," would assist with the project. $^{11}$ Several weeks later another Wyoming Tribune article reported the unqualified support of Hollywood actor Wallace Beery who first visited Jackson Hole in 1900 and owned a cabin on Jackson Lake. Beery professed there was no better place for such an extensive display of Wyoming wildlife. ${ }^{12}$

Yet Fabian had been correct to express concern about potential opposition. Perhaps the most distressing critique of the wildlife park came from another Jackson Hole resident, renowned wildlife biologist Olaus J. Murie. Murie critically echoed a New York Herald Tribune article that referred to the proposed park as a zoo. The article made no mention of the possibility of any biological research, instead focusing on its function as a tourist attraction. Murie publicly voiced his disapproval of the plan, explaining that confining game animals in a specific area created the "antithesis" of a natural, healthy habitat. $\mathrm{He}$ claimed that the public could be provided the opportunity to readily view wildlife without the use of enclosures. Stunned by the fact that the project had been approved without receiving input from all of the members of the Jackson Hole Preserve board of directors, of which he was one, and that they were not informed prior to disclosure of the planned project by the press, Murie resigned from the board. ${ }^{13}$

A highly regarded conservation organization, the Isaac Walton League of America (IWLA), also opposed the "zoo." As chairman of the Committee on Conservation of the national organization, John W. Scott wrote to Richard Winger, president of the Jackson Hole chapter of the League regarding the proposed JHWP. Scott acknowledged the educational value of zoological gardens when located near urban areas but questioned the placement of such a facility in Jackson Hole. He argued that "it [the proposed wildlife park] would be out of place, highly expensive with no important worthwhile function and even highly grotesque and ridiculous." He professed that when Gov. Hunt had presented the plan in early August to the State Convention of the Wyoming Division of the League that it received a "cool reception" and that most delegates did not take the

11 "Big Wildlife Exhibit to Be Set Up," Wyoming Tribune, October 2, 1945, Box 2, Folder 1945, Winger Papers.

12 "Wildlife Park Plan Praised," Wyoming

Tribune, November 12, 1945, Box 2, Folder 1945, Winger Papers.

${ }^{13}$ Olaus J. Murie to Vanderbilt Webb, November 4, 1945, Box 2, Folder 1945, Winger Papers; "Jackson Hole Wildlife Park," National Park Service, governor seriously. Scott also expressed concern about Wyoming's continued financial commitment to maintaining the facility considering the volatility of state and local politics. ${ }^{14}$

However, Winger's interest in conservation went beyond his association with the IWLA. As an agent of the Snake River Land Company he had been involved with the purchasing of the properties in Jackson Hole. He had also been involved in the establishment of the JHNM. Winger was still working for Rockefeller at JHP when this new venture arose. He felt that the prospective benefits of the proposed wildlife park far outweighed the possible negative aspects that concerned its detractors. Winger's intimate knowledge of the valley enabled him to counsel Rockefeller and the other board members of the soon to be created Jackson Hole Game Park, Inc. regarding the selection of the site for the preserve as well as other important aspects.

\section{$\uparrow \quad$ EARLY PLANNING}

The tract of land chosen for the JHWP ran along Highway 287 between Jackson Lake Junction and Pacific Creek, with the primary viewing area located on the south side of the highway, southeast of Oxbow Bend. The plan Winger suggested called for erecting fencing at the south end of the property that would funnel animals into the Park as they left the National Elk Refuge and lower elevations of the valley during the spring migration. During the spring and fall, fencing at the northern and southern boundaries would be lowered, allowing most animals to pass through. At the right time during the spring migration the fencing would be reset in order to contain a minimum number of animals for the summer tourist season. Winger hoped that any calves born inside the JHWP grounds would voluntarily return to the Park, the only summer range they knew, after being allowed to leave during the fall migration. He envisioned the development of a JHWP herd that would always summer in the park, allowing all fencing to be removed. ${ }^{15}$

http://www.nps.gov/grte/historyculture/jhwp.htm, [accessed February 18, 2013]; "Zoo in Bronx Given a Home on the Range," New York Herald Tribune, November 2, 1945, Box 2, Folder 1945, Winger Papers.

14 John Scott to Winger, December 5, 1945, Box

2, Folder Wildlife Park, Winger Papers.

${ }^{15}$ Winger to LSR, July 10, 1946, Box 1, Series 2, Folder 5, RG5 GTNP; also in Box 2, Folder Wildlife Park, Winger Papers. 
Winger's plan addressed two problems. He understood the concerns of many people regarding the artificial confinement of wild animals, in fact he agreed. And he believed that any necessary fencing should be placed where it would have the least visual impact in order to maintain the natural appearance of the landscape. Keeping both of these concerns in mind, his plan called for the eventual removal of almost all fencing. He believed that this strategy would mitigate the main objection to the JHWP by the conservation community. The expense of artificial feeding during the winter created another problem. By enabling the animals to migrate out of the Park, the cost of feed for the animals as well as salaries and housing costs for staff during the winter could be minimized, if not eliminated. ${ }^{16}$

Another individual instrumental to the development and initial success of the JHWP was James R. Simon. Backed by a degree in zoology and experience both as a ranger in Yellowstone National Park and as a commissioner with the Wyoming Game and Fish Department (GFC), Simon became the first director of the wildlife park in October, 1946. More than anyone else he articulated the purpose, goals, and challenges of the JHWP. He understood that quelling opposition to the park relied on communicating all of its potential benefits to the public. ${ }^{17}$

Even at this early stage of development, almost two years before the park opened, Simon comprehended the importance of education and research to the future success of the project. Simply displaying game animals was not enough; he advocated a multi-faceted approach to inform visitors about the animals' unique characteristics and the importance of each species to the entire ecosystem of Jackson Hole. Yet he also wanted areas that would demonstrate the negative consequences of having too many animals in a given area - overgrazing, highlining of trees, soil depletion, and erosion. Through such displays he hoped people would gain an understanding of the importance of natural resource and wildlife management to the survival of the animals and the conservation of the landscape. Simon gave equal consideration to the development of research programs. ${ }^{18}$

Simon also appreciated the dire need of state and federal agencies for verifiable information on which to base hunting and fishing policies. He knew

\footnotetext{
${ }^{16}$ Ibid

${ }^{17}$ Simon, "The Jackson Hole Wildlife Park," Box 2, Folder 1945, Winger Papers; also located in Box1, Folder 17, Lester C. Hunt Collection, American Heritage Center,
}

that the demands of WWII caused many studies to be abandoned before their completion. With the support of Governor Hunt, Commissioner Bagley, the NYZS, and the board of the JHWP, Simon sought to revive some of the old, unfinished research projects and to launch new ones. He envisioned three different approaches to wildlife research. First, he wanted to support independent scientists who would conduct studies of the animals and plants that occupied the various habitats found within the wildlife park. Second, Simon sought to establish a cooperative relationship with state and federal agencies. He wanted the capability of offering the expertise of a resident biologist to take over smaller-scaled studies that such agencies were not able or willing to undertake for themselves. He also wanted to be able to offer to the scientists of those same agencies the use of the research facilities within the park. To that end he called on the board to order a comprehensive facilities development plan that would include a fullyequipped laboratory, dormitories and other accommodations for guest researchers and staff, an office, library, and an information/education center for tourists. Finally, Simon wanted to develop relationships with educational institutions by providing opportunities for students to conduct much needed fieldwork studies to enrich their academic experience. He hoped to attract students from a variety of disciplines - plant biology, aquatic studies, and any number of other animal sciences - in addition to wildlife management. As committed to conservation as Rockefeller and Fairfield Osborn, head of the New York Zoological Society, Simon joined in their vision of the Jackson Hole Wildlife Park as a leader of wildlife and ecological scientific research. ${ }^{19}$

These two men contributed significantly to the planning and development of the wildlife park and its facilities. Winger, having lived in the valley for over thirty years, provided invaluable knowledge of the migration movements and behaviors of Jackson Hole's wildlife. Simon drew on his educational and professional experiences. Both of them worked diligently to overcome obstacles in order to create something more than a roadside tourist trap, to realize Rockefeller's goal of educating the public about the importance of habitat and wildlife conservation through visual engagement with the majestic animals of the West.

University of Wyoming, Laramie, Wyoming (hereafter referred to as the Hunt Papers).

$$
{ }^{18} \text { Ibid. }
$$$$
{ }^{19} \text { Ibid. }
$$ 


\section{PLANNING FOR THE WILDLIFE PARK CULMINATES IN REALITY}

Almost three years of planning and development transpired before JHWP became a reality. Aside from the creation and staffing of a business to oversee the operation of the park, the actual boundaries needed to be determined, fencing installed, structures built, and animals acquired. As with any project, each task generated additional questions and challenges.

Establishment of the administrative structure occupied much of the winter of 1945 and 1946. The most immediate task, accomplished in December, entailed the incorporation of a non-profit entity called Jackson Hole Game Park led by a nine member Board of Trustees. The original trustees, also called directors, included Rockefeller, Fairfield Osborn (president of the NYZS) and Alfred Ely (vice president of the NYZS) who represented the NYZS; Lester Bagley, Carl Jorgenson, Foster S. Scott and Gilbert O. Housley represented Wyoming; Kenneth Chorley and Harold Fabian represented JHP. ${ }^{20}$

Article 2 of the Certificate of Incorporation clearly identified the purposes of the corporation:

"The purposes for which the corporation is formed are exclusively charitable, educational and scientific; for promoting the diffusion of knowledge and useful information concerning wild fowl and game native to the State of Wyoming and other localities...; for providing and maintaining a suitable place or places for the collection, exhibition and preservation of such wild fowl and game; to provide, establish and maintain parks, roads and trails; and for the preservation of the history and tradition of the country, particularly with respect to the Jackson Hole area; and in general to promote, manage and conduct such other and further activities as are germane to these general purposes."21

As delineated, determining the best location for the housing and exhibition of the animals, and acquiring the chosen land (see Figure 2) demanded an analysis of terrain, including existing roads, streams, and trails,

20 Certificate of Incorporation, November 26, 1945, Box 1, Series 1, Folder 2, RG5 GTNP; Fabian to Winger, November 9, 1945, Box 2, Folder Wildlife Park, Winger Papers.

${ }^{21}$ Certificate of Incorporation, RG5 GTNP

${ }^{22}$ News Release, January 2, 1946, Hunt Papers; Revocable Permit, March 22, 1946, and JHP lease to JHWP, July 1, 1946, Box 4, Series 10, Folder 2, RG5 GTNP. a process that began almost immediately after Rockefeller approved the plan in August. Following incorporation, executing a lease for the selected land from Jackson Hole Preserve and acquiring a permit from the federal government for use of adjoining public lands in the Jackson Hole National Monument became two of the board's most important tasks. The Department of the Interior issued the lands use permit on March 22, 1946. The Board of Trustees finalized a lease for the majority of the needed land from JHP a few months later. Below is a simplistic map showing the location of the 1,500 acre JHWP. ${ }^{22}$

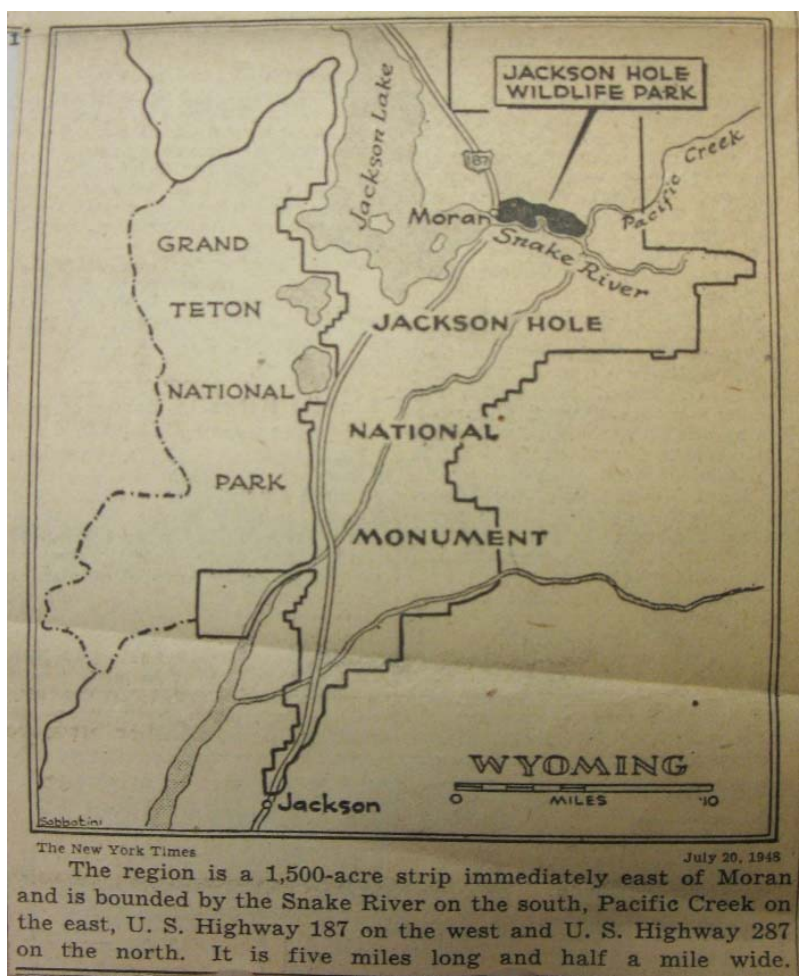

Figure 2. Location of the JHWP relative to GTNP and JHNM. $^{23}$

The summer of 1946 witnessed one other significant administrative action. On June $26^{\text {th }}$ the name of the park officially changed from Jackson Hole Game Park to Jackson Hole Wildlife Park. ${ }^{24}$ No verifiable explanation for the change has been located. However, it can be assumed that since the park and its affiliated research program intended to include fish,

${ }^{23}$ This map, taken from a July 20, 1948 New York Times article covering the dedication ceremony of JHWP, shows the approximate boundaries of the park; missing is Highway 287 which runs east from Moran along the northern edge of the park. Box 1, Folder 17, Hunt Papers.

24 Certificate of Incorporation, and Proof of Publication, RG5 GTNP. 


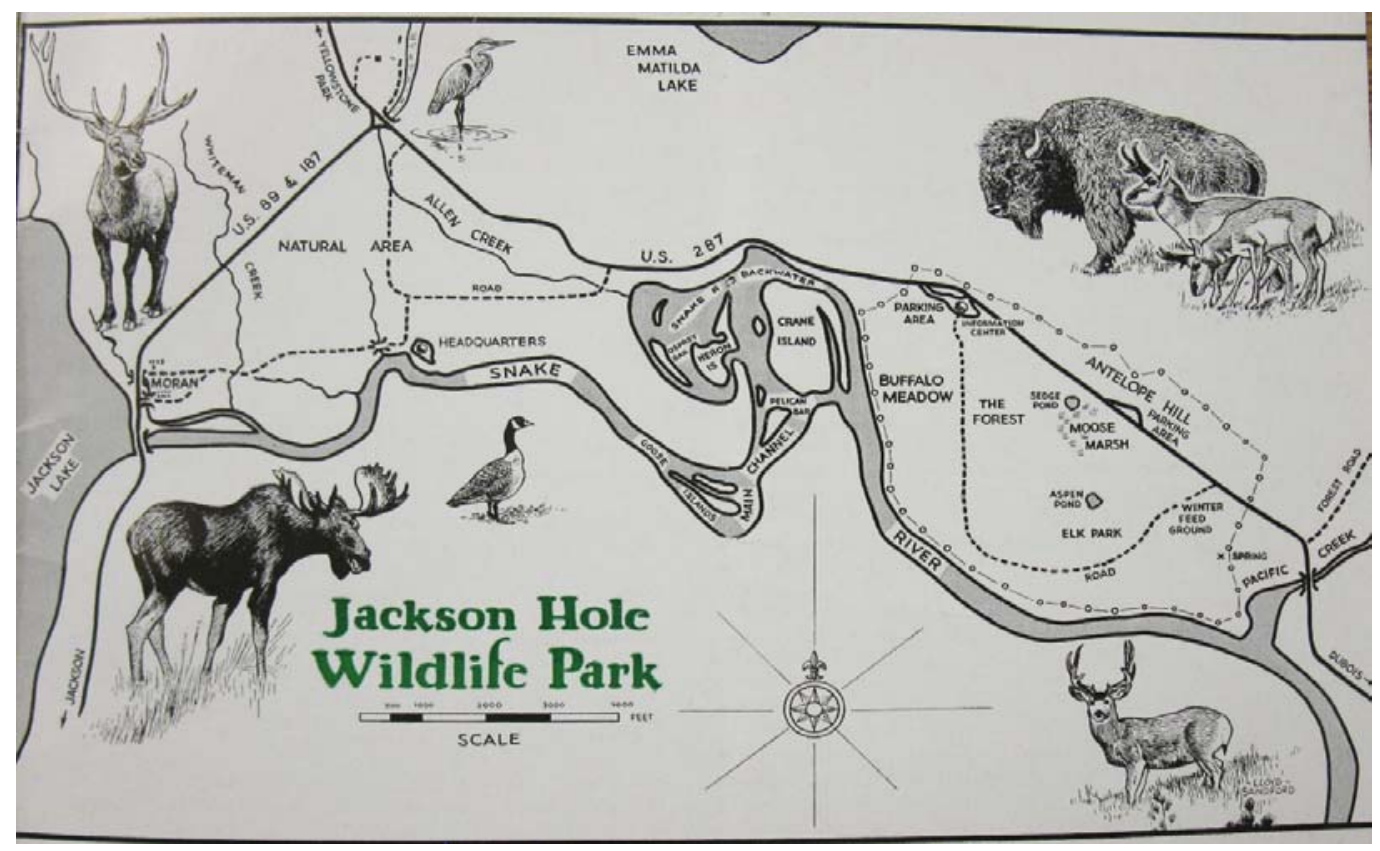

Figure 3. Attendants of the opening ceremony received a booklet that included this map. ${ }^{25}$

birds, and other animals as well as plants in addition to game animals the choice of "Wildlife" was deemed more representative of the functions of the park.

The critical issues of where to locate the public viewing area and placement of fencing followed. As agent of the JHWP responsible for the daily activities and management of the Park, Winger assumed the task of assisting Dr. Jean Delacour in establishing the physical arrangement of the facility as soon as weather and snow levels permitted late in the spring of 1946. Once the plan was approved, Winger was to oversee construction of the fencing. ${ }^{26}$ When Delacour's proposed layout appeared at odds to Winger's vision and goals for the Park, he communicated his concerns to Rockefeller and other members of the Board of Trustees. Time taken to consider his alternative recommendations delayed the first phase of fencing installation by several months. The delay ultimately caused the postponement of the park opening from 1947 to $1948 .^{27}$ Installation of other control measures such as cattle guards in the adjacent highway required approval by and cooperation with the Wyoming Highway Commission and/or the Game and Fish Commission. ${ }^{28}$

Following completion of the fencing and cattle guards surrounding the exhibition area late in 1947, JHWP scheduled the introduction of its game animals for early 1948. Simon secured numerous elk and three moose from the Park's grounds. Commissioner Bagley made arrangements for the State Game and Fish Department to provide the other desired game animals. After making inquiries with the

${ }^{25}$ Jackson Hole Wildlife Park, July 1948, Box 5 ,Series 13, Folder 1, RG5 GTNP.

${ }^{26}$ Fabian to Winger, November 9, 1945, Box 2, Folder Wildlife Park, Winger Papers. Dr. Jean Delacour, a renowned ornithologist, served as a technical advisor and researcher affiliated with the NYZS during the 1940s. See Delacour obituary, New York Times, November 29, 1985, http://www.nytimes.com/1985/11/29/world/dr-jean-delacour-95-leading-ornithologist.html and Jean Théodore Delacour, Wikipedia, http://en.wikipedia.org/wiki/Jean Th\%C3\%A9odore Delacour.

${ }^{27}$ The delay, combined with different approaches to the design of the park, may also have been a contributing factor in Simon being appointed director of the corporation during a meeting of the Executive Committee held on August 12, 1946. The following summer the trustees terminated Winger's positions as Superintendent of Construction and legal Resident Agent of the JHWP, Inc. Simon was named Resident Agent and as Director he assumed responsibility for all construction projects. Report to the Board of JHWP, February, 1947, Box 1, Folder 17, Hunt Papers; Certificate of Appointment of Agent, August 26, 1947, Box 4, Series 10, Folder 5, RG5 GTNP.

${ }^{28}$ Fabian to Winger, November 9, 1945, and Fabian to Bagley, June 26, 1946, Box 2, Folder Wildlife Park, Winger Papers; "Report to the Board of JHWP," February, 1947, Box 1, Folder 17, Hunt Papers. 
superintendents of both Wind Cave and Yellowstone National Parks, twenty bison were delivered from Yellowstone. The State also provided seventeen antelope, nineteen mule deer, and ten white-tailed deer. $^{29}$

When the Jackson Hole Wildlife Park finally opened on July 19, 1948, like any large scale enterprise it was still a work in progress but much had already been accomplished. In addition to the erection of fencing and the installation of the game animals a visitor information center stood at the primary exhibition area overlooking Buffalo Meadow and interior observation roadways had been constructed to allow visitors close access to the animals. A hayshed to store feed had been erected near the winter feeding ground. And in consideration of motor tourists Simon had enlisted the assistance of the State Highway Department with the installation of highway turn-outs and parking areas. The map in Figure 3 shows the location of some of these key features.

However, the changing public perception of JWHP proved to be equally as important as the physical developments. As the endeavor took shape, moving beyond just a vague concept to tangible reality, many people began to appreciate the park's potential not only as a tourist attraction but also its capacity to advance conservation. As early as February 1947 Simon reported that the National Park Service Association ${ }^{30}$ withdrew its disapproval and the JHWP had garnered the support of the Dude Ranchers Association. ${ }^{31}$ In September the American Society of Mammologists expressed its desire for the park to "abandon plans for any unnatural presentation of wildlife" but fully endorsed the "emphasis on research"32 The JHWP received another unqualified endorsement from the Wyoming Federation of Sportsmen's Clubs in March, 1948. ${ }^{33}$

To measure the opinions of the general public living in and visiting Jackson Hole as compared to special interest groups, Osborn commissioned a survey conducted during the summer of 1947. Carried out by Dr. C. R. Carpenter of Pennsylvania State

\footnotetext{
${ }^{29}$ Simon, "Report to the Board of the JHWP," April 1, 1948, Box 1, Folder 17 Hunt Papers.

${ }^{30}$ The NPS Association is not to be confused with the NPS, which remained mute regarding the JHWP.

${ }^{31}$ Report to the Board of JHWP, February, 1947, Box 1, Folder 17, Hunt Papers.

32 Donald F. Hoffmeister to Newton Drury, September, 16, 1947, NPS: Grand Teton National Monument, Box 2, Folder 201-Correspondence, National Archives and Records Administration (NARA), Broomfield, Colorado.
}

College (now Pennsylvania State University), it showed broad support for the park. Of those interviewed, 74.7 percent approved of the development of the wildlife park and an overwhelming 88.0 percent endorsed an affiliated research and training center. ${ }^{34}$ As the JHWP took shape and people learned more about it opposition diminished and support expanded.

\section{Dedication of Jackson Hole Wildlife Park}

As reported by Fabian, the dedication was a classic Rocky Mountain summer event held on a beautiful day, in a beautiful setting, with an afternoon thunderstorm that threatened but held back until the conclusion of the ceremony. Surprisingly, only a handful of the approximately five hundred people who attended hailed from the nearby town of Jackson. ${ }^{35}$ Rockefeller delivered the keynote address. His speech chronicled the origins and development of the JHWP, identifying key participants and their contributions. He also told of his family's first visit to Jackson Hole in 1924, of his father's desire to protect the area from over development and of his land purchases, suggested by then Yellowstone Superintendent Horace Albright, which resulted in the availability of the land for the JHWP. Rockefeller clearly stated the goal of the new Park: "In short, our objective is to have the scenery, the wildlife, and the historic past of Jackson Hole conserved for, not from, the people who live and visit here...We believe that the JHWP, dedicated here today, will prove to be another important step toward the realization of the general objectives of the Jackson Hole project. The people who come here will see wildlife, they will learn to identify the various animals and birds, to appreciate them, understand the problems involved in their protection, the need for preserving forests, safeguarding watersheds, saving the wilderness - in effect, the people will see what they are asked to conserve." ${ }^{\prime 36}$ Reprinted in full by the Jackson Hole Courier, the public enthusiastically embraced Rockefeller's commitment to the valley. They especially appreciated his comments about the JHWP and the

33 "Resolution by Wyoming Federation of Sportsmen's Clubs," Game and Fish/Administration, Director Files, 1946-49, S-Z, Wyoming State Archive, Cheyenne, Wyoming.

34 Osborn to Fabian, November 21, 1947, and attached report, "Information Schedule on Jackson Hole Region," Box 4, Series 4, Folder 3, RG5 GTNP.

${ }^{35}$ Fabian to Boyer, July 20, 1948, Box 5, Series 13, Folder 1, RG 5 GTNP.

36 LSR, "Remarks Made at the Opening Ceremonies of the JHWP," July 19, 1948, RG5 GTNP. 
entire JHP strategy of conservation and preservation being for everyone's benefit. Fabian believed that "his [Rockefeller's] talk at the opening of the Wildlife Park did more than any single thing that has happened to bring local public good-will to the entire Jackson Hole Preserve effort." 37

Little real advertising of the JHWP has been discovered. Most publicity and information about the Park appears to have been disseminated through newspaper articles. The local newspapers of Jackson Hole, the Salt Lake Tribune, and the New York Times often printed updates about the activities of the Park. ${ }^{38}$ Those and other papers such as the Denver Post printed informative pictorial layouts, often paired with informative articles. ${ }^{39}$ Animal Kingdom, published by the NYZS, printed several articles informing its readers about current happenings. ${ }^{40}$ And the Wyoming Commerce and Industry Commission produced booklets and brochures called Wonderful Wyoming similar to today's tourism pamphlets, advertising the wonders of the Wyoming, including the Teton Mountains, but did not specifically mention the JHWP. ${ }^{43}$ Simon, presumably with the Boards approval, apparently preferred a targeted approach of localized marketing.

Several of Simon's reports to the Board of Directors and the Advisory Board discussed other means of drawing visitors to the Park. In cooperation with the Jackson Chamber of Commerce, JHWP staff hosted guided tours of the Park to attendees of conventions held in Jackson. GTNP included the Park in its offerings of guided tours and JHWP staff often informed campers about the Park and its animals during NPS campfire programs. A taxi service provided transportation from Moran for those travelling by bus who wanted to see the exhibit. Simon also reported that two saddle horse outfits near the Wildlife Park prioritized visiting the facility during guided rides. He seemed most pleased by the attendance of visitors and residents of Jackson Hole to talks given by researchers about their work. He also let it be known that travel agents across the country

${ }^{37}$ Fabian to Boyer, July 30, 1948, Box 5, Series 13, Folder 1, RG5 GTNP.

${ }^{38}$ Multiple newspaper clippings located in several collections - Winger Papers, Hunt Papers, RG5 GTNP, and the Rockefeller Family Papers, Rockefeller Archive Center (hereafter referred to as RAC), Sleepy Hollow, New York.

RAC.

39 Kenneth Chorley Papers, Box 2, Folder 21,

40 Ibid.; Animal Kingdom: The Magazine of the NYZS, Vol. LI, No. 5, October 1, 1948, Box 5, Series 13, Folder 1, RG5 GTNP. had requested information about the JHWP to include in their travel brochures. ${ }^{41}$

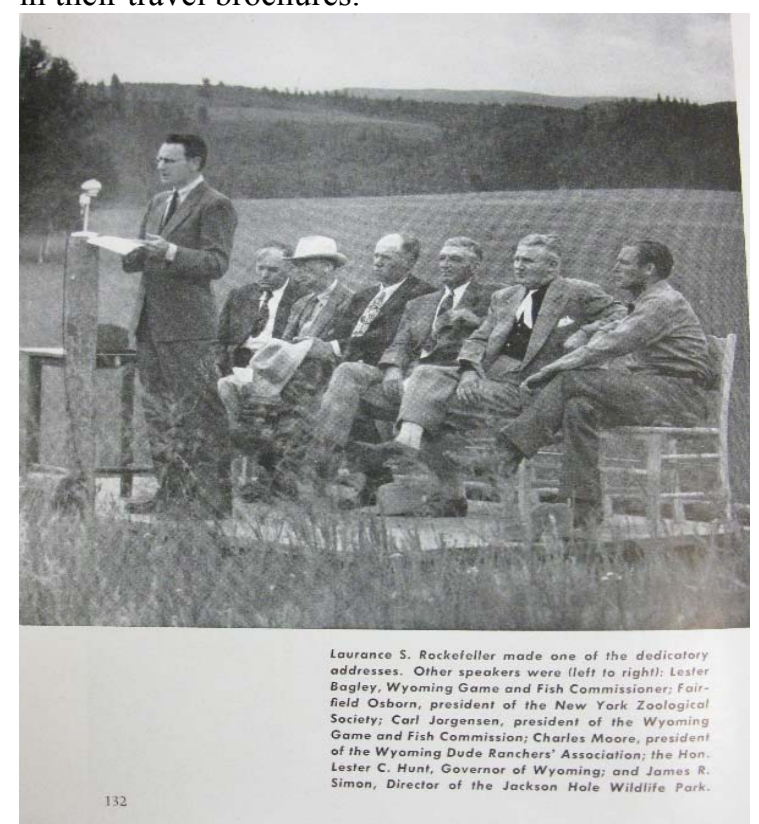

Figure 4. Rockefeller delivering the keynote address. Photo acquired from the same Animal Kingdom article as Figure

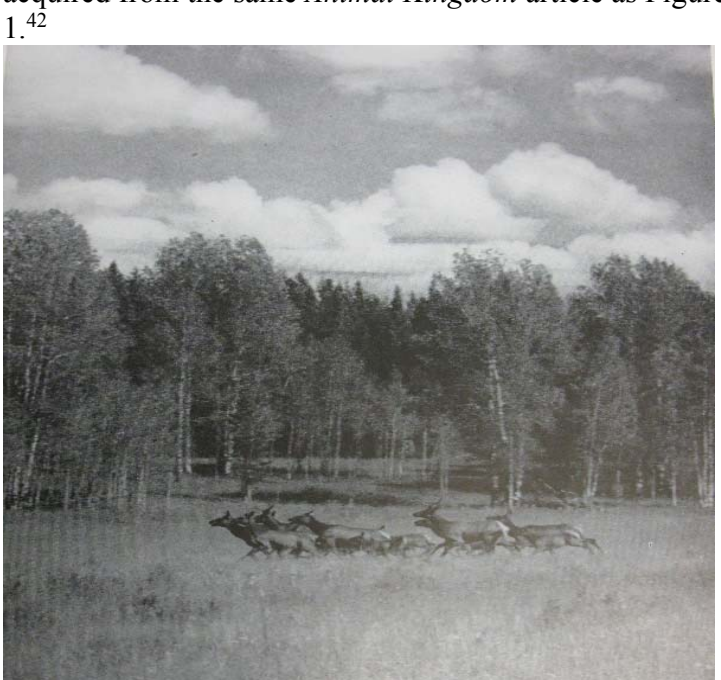

Figure 5. Elk passing through a meadow in the JHWP. Photo acquired from the same article as Figure 1. During the dedication ceremony a horseman kept elk and bison behind the speakers' platform within view of the spectators. ${ }^{43}$

${ }^{41}$ Simon, Reports, 1950-52, Box 18, Folders 15 and 16, Neal Blair Papers (hereafter referred to as the Blair Papers), AHC.

42 "The Inauguration of the Jackson Hole Wildlife Park," Animal Kingdom: The Magazine of the NYZS, Vol. LI, No. 5, October 1, 1948, Box 5, Series 13, Folder 1, RG5 GTNP.

${ }^{43}$ Fabian to Boyer, July 20, 1948, Box 5, Series 13, Folder 1, RG5 GTNP. 


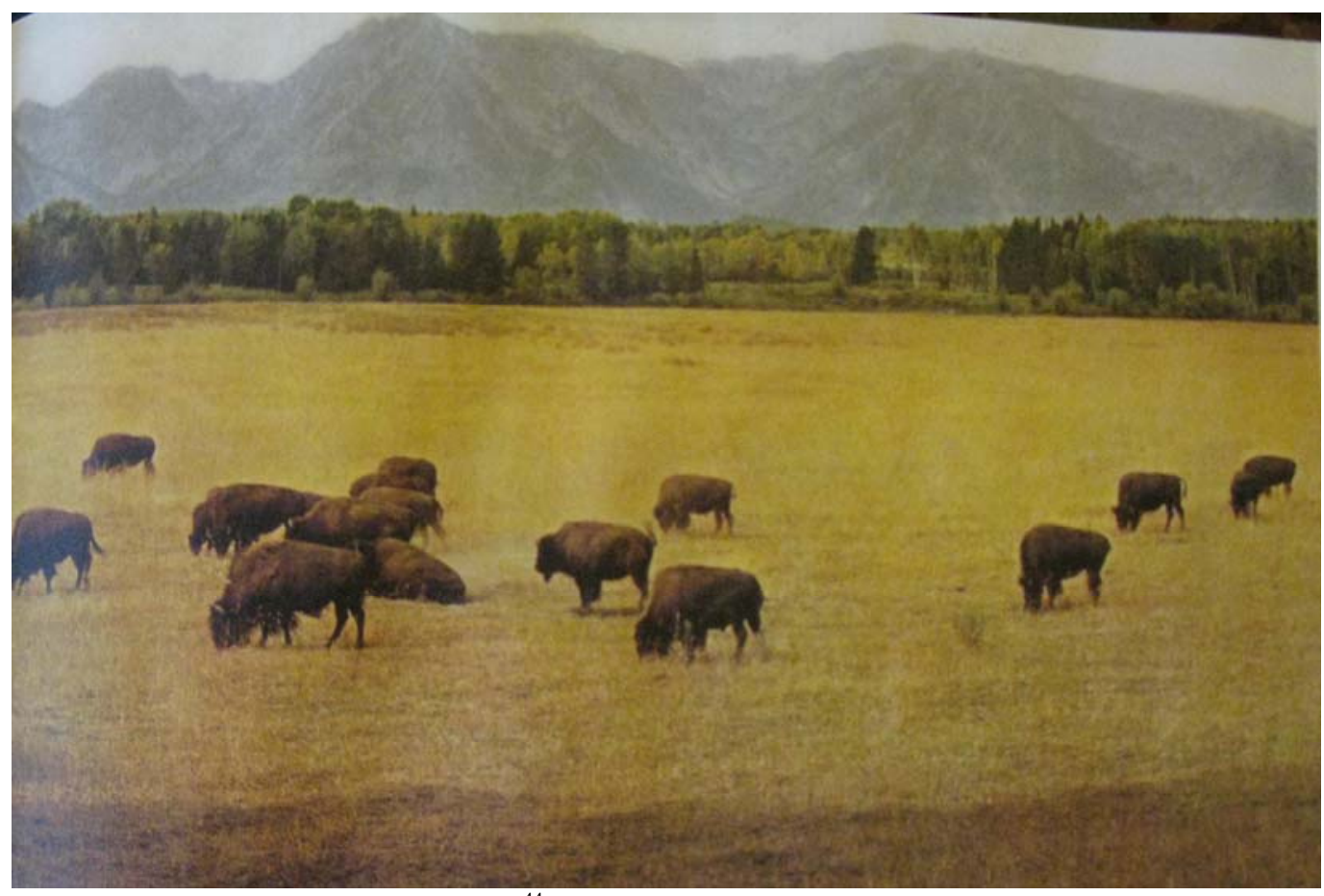

Figure 7. Bison grazing in JHWP, c. $1955 .^{44}$

The State Game and Fish Commission reported that during 1949, the JHWP's first full summer season in operation, approximately 86,000 persons visited the Park. They came from twenty-four foreign countries and almost every state in the nation. ${ }^{45}$ The following year (measured from September 15, 1949 to September 15, 1950) saw only a modest increase of just 3,000 visitors. But attendance skyrocketed during the 1950-51 period with the total number of visitors estimated at over 105,000. The JHWP typically opened for the tourist season on June $15^{\text {th }}$ and closed on September $15^{\text {th }}$. Therefore Simon had to estimate the total number of visitors, adding to the count recorded at the Visitor Information Center and the antelope enclosure to account for those who stopped to observe the animals during the rest of the year. Visitors enjoyed the experience of seeing elk, bison, white-tail and mule deer, and antelope all in one central location, the
Buffalo Meadow. By all accounts, as a tourist attraction, the JHWP was amazingly successful. ${ }^{46}$

It was equally successful at establishing and growing its bison herd. In January 1948, twenty bison arrived at the JHWP, including fourteen females between one and four years of age. That spring four of the cows produced calves. The following year eight of them gave birth to one calf each. ${ }^{47}$ The Game and Fish Department had provided the original seed herd on the provision that any offspring could be claimed by the Department. The first documentation of the possible removal of excess bison occurred in October 1949.48 The State did remove six bison in the fall of 1950 but it is not known if they were delivered to Mr. Faulkner. However, in August 1951, Simon reported that the herd had grown to forty-five and that Game and Fish Department personnel removed twenty-three of those to start two new herds for the State. ${ }^{49}$ Once again the JHWP could claim success, this time through a productive breeding program.

\footnotetext{
${ }^{44}$ Newhall, A Contribution, 111.

${ }^{45}$ Game and Fish Commission 1949 Annual Report, Box 18, Folder 13, Blair Papers.

${ }^{46}$ Simon Report, June 15, 1950 and October 15, 1951, Box 18, Folder 15, Blair Papers.

${ }^{47}$ Norman C. Negus, "Breeding of Three-Year-Old Females in the Jackson Hole Wildlife Park Buffalo Herd," Journal of Mammology 31, no. 4 (1950), 463.

${ }^{48}$ Lester Bagley to Art Faulkner, October 7, 1949, Game and Fish/Administration, Director's Correspondence, 1946-49, A-F, Wyoming State Archives.

${ }^{49}$ Simon Reports, October 15, 1950 and August 15, 1951, Box 18, Folder 15, Blair Papers.
} 


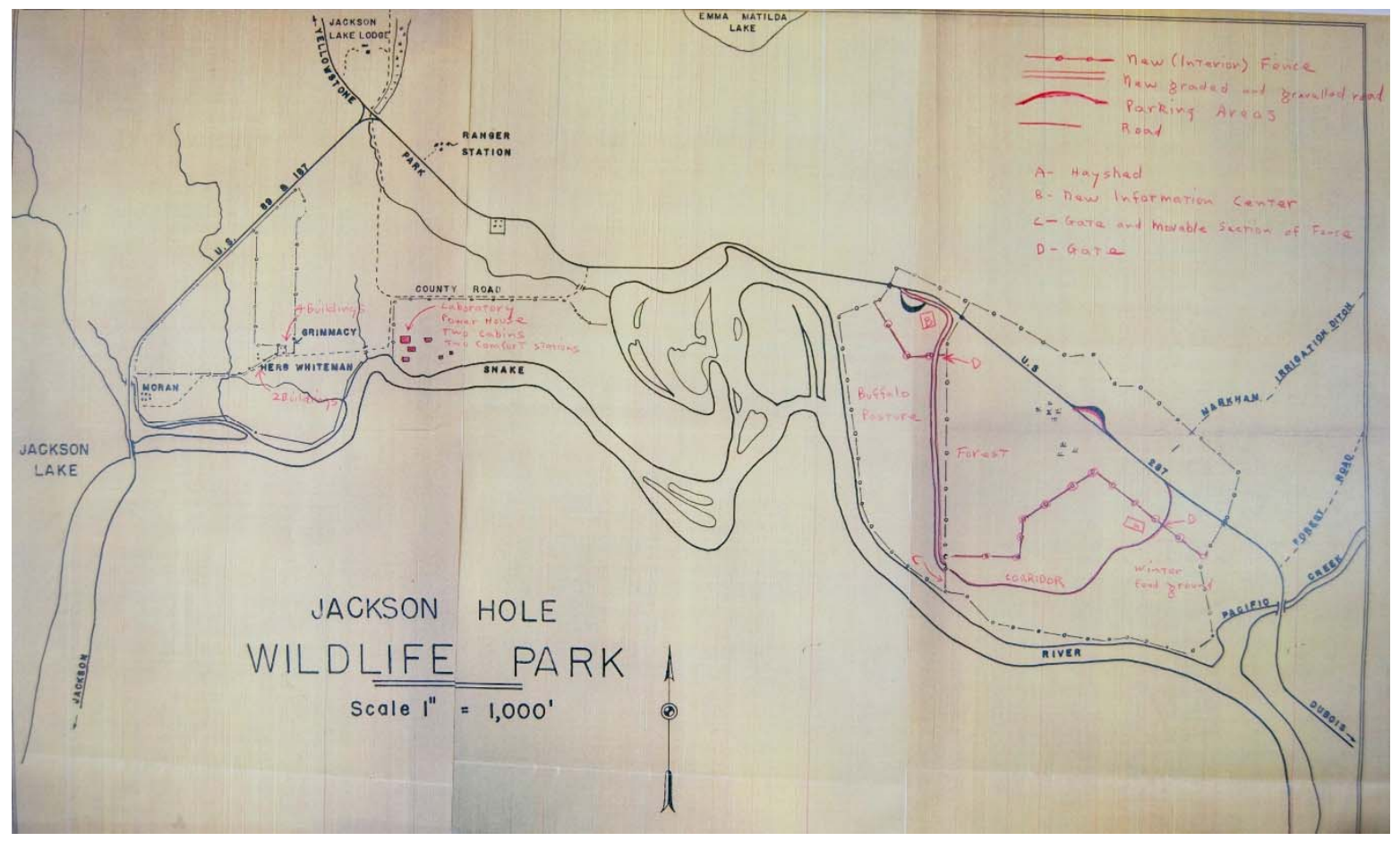

Figure 8. Map of the JHWP at the end of 1948 showing the location of the research field station complex near the west end of the Park, new interior fencing, and the new information center. ${ }^{50}$

\section{EARLY DEVELOPMENT OF THE BIOLOGICAL RESEARCH STATION}

The early demand for use of the park as a research facility surprised everyone. The first formal scientific study conducted on the grounds took place in September, 1946 as construction on the first sections of fencing began. Dr. E. Raymond Hall led a group of mammalogists from the University of Kansas who investigated the migration patterns of elk through the park. Information gleaned from their study helped determine the location of later phases of fencing. ${ }^{51}$ During the summer of 1947, a year before JHWP formally opened to the public, twenty-three individuals, including sixteen students, from seven different institutions conducted research at the park. The Park hosted another twenty researchers the following summer. As demand grew so did a complex of buildings designed specifically to house and support researchers and their work. ${ }^{52}$
Simon's contractors kept very busy during the summer of 1948 hoping to complete as much work as possible before winter descended on the valley. The plans included the construction of a laboratory, three cabins, a powerhouse, and two outhouses. Later in the summer, after the completion of the JHWP visitor information center, a small cabin was moved to the research complex to serve as a library. Simon stocked the new laboratory with new scientific and photographic equipment. He also added to the small library collection. Each year the facility expanded, gaining additional housing for staff and researchers, a bath house, and a mess hall. Rockefeller and the NYZS funded the vast majority of these capital improvements. ${ }^{53}$

Simon and Osborn in particular took great pride in the volume and quality of scientific studies conducted at the Park. However, it created conflict and concern for Bagley and the other members of the Game and Fish Commission on two fronts. First, the original concept as envisioned by Bagley, Hunt, and

501948 Map, Map Folder C-1, File 9, Grand Teton Lodge Company, RAC.

${ }^{51}$ Simon Report, February, 1947, Box 1, Folder 17, Hunt Papers.

${ }^{52}$ Meeting Minutes, August 26, 1947, Box 1, Folder 17, Hunt Papers.

${ }^{53}$ Lenore Diem, "The Research Station's Place in History, Historical Chronology of the establishment and Development of the Jackson Hole Biological Research Station," NPS, www.nps.gov/history/history/online books/npsg/research station/chronology.htm (accessed February 1, 2013); Simon Report, February, 1947, Box 1, Folder 17, Hunt Papers. 
Miller emphasized the animal display, not the research facility, which in their minds provided a supplemental service not a primary activity. Additionally, the Game and Fish Department also conducted research which created a conflict of interest. Therefore, the commissioners dictated that all of the funds they contributed be spent exclusively in support of the animal display. In part because of the position of the Game and Fish Commission and the growing use of the biological field station, that portion of the complex became known as the Jackson Hole Biological Station of the NYZS early in 1950. As a result of the direct affiliation with the Zoological Society, the society began a grant program providing funding for researchers conducting studies at the Biological Station. That summer twelve individuals received grants. $^{54}$

\section{Evolution of the JHWP and the Biological Research Station}

Despite some growing pains and a few unanticipated challenges, success seemed a certainty for the JHWP. Thriving animals, escalating visitorship, and steady use of the research field station created a perfect mix. Yet the political landscape started changing and the Wildlife Park found itself caught in the middle. In fact, the tide started turning back in the closing months of 1949. By 1952, Jackson Hole Wildlife Park, Inc. would no longer exist.

The process began when, on October 31 , 1949, the NPS extended the public land use permit allowing the JHWP use of over six hundred acres in the Jackson Hole National Monument (JHNM) until October 31, 1959. The previous permit, written for a five year term, had been scheduled to expire in 1952 . JHP matched the NPS permit, extending its lease of land to the JHWP to the same date thus virtually guaranteeing that the Wildlife Park would continue to operate for another ten years. ${ }^{55}$ Perhaps both parties no longer viewed the JHWP as an experiment but as a viable entity.

What happened next really should not have surprised anyone. Two months later, on December $16^{\text {th }}$, JHP transferred to the federal government the deeds to the 33,562 acres of land in Grand Teton National Park and the JHNM purchased almost twenty years earlier. The dream of John D. Rockefeller, Jr. and his son for the United States to own and manage

\footnotetext{
${ }^{54}$ Simon Reports, February 15, 1950 and June 15, 1950, Box 18, Folder 16, Blair Papers.

${ }^{55}$ Fabian to Simon, December 19, 1949, Box 4, Series 10, Folder 5, RG5 GTNP.
}

the land on behalf of all Americans became a reality. But though the land would be managed by the NPS, it was not yet included in GTNP which was the senior Rockefeller's ultimate goal. ${ }^{56}$

On September 14, 1950 the future of the JHWP unknowingly stepped onto a decidedly different path. On that day the years' long battle to abolish Jackson Hole National Monument (JHNM), which housed the grounds of the JHWP, and to contain Grand Teton National Park (GTNP) ended. President Truman signed into law legislation that did in fact abolish JHNM, but it simultaneously incorporated the former Monument into an enlarged GTNP. John D. Rockefeller, Jr. and Albright celebrated the victory of their long fought crusade. ${ }^{57}$ Laurance celebrated too, but he also had reason to be concerned about the wildlife park that he and others had worked so diligently to create.

With the JHWP now wholly within a national park, the views and policies of the NPS could not be ignored. From the beginning everyone involved with the Park knew that the NPS opposed its development. Ever since Albright's "zoo" in Yellowstone closed in the late 1920s the agency had progressively turned away from such animal displays. NPS Director Newton Drury quietly expressed his opinion that the "experiment" of the JHWP would fail and thus validate the agency's policy against confinement of wild animals. ${ }^{58}$ Now, in late 1950, Rockefeller felt that the time had come for him to concentrate on other projects but he worried about who would assume responsibility for running the JHWP if he and the NYZS backed away.

1951 experienced a quiet, relatively uneventful beginning. A technical change transpired in May that dealt exclusively with the research station. The organization changed its name from the Jackson Hole Biological Station of the NYZS to the Jackson Hole Research Station of the NYZS (JHRS). On the surface it seemed a mere formality but the simultaneous drafting of a policy statement enhanced the professionalism of the Research Station. Perhaps because of its affiliation with the JHWP, the Research Station declared its main purpose "to promote research in the broad field of ecology with special emphasis on animal behavior." Reflecting the influence of Simon, the policies also stressed the importance of cooperative relationships with colleges and

\footnotetext{
Papers.

56 Press Release, Box 2, Folder 1949, Winger

${ }^{57}$ Righter, Crucible, 140-141.

58 Ibid., 130-131.
} 
universities, museums and other institutions, and especially State and Federal government agencies whose responsibilities were tied to the local area. ${ }^{59}$ The formalization of the JHRS and a mid-summer visit to the JHWP by former Gov. Miller caused concern about the future of the wildlife park.

The possibility of the Game and Fish Commission (GFC) taking over the operation of the wildlife exhibit developed over a few short weeks in July. It began with correspondence between former Governor Leslie Miller and Lester Hunt, by then no longer Wyoming's governor but a U. S. Senator. Both men expressed their serious disappointment with the condition of the animal display. Miller reported that when he visited the JHWP just a few weeks earlier the exhibit area did not contain any moose, deer, or antelope, just elk and bison. They shared the opinion that the original purpose of the JHWP, the exhibition of Wyoming's game animals had been supplanted by the research activities. Still convinced that it could "be made one of the greatest attractions for tourists in the whole of the United States..., especially for children," Hunt proposed that the GFC assume control and operation of the wildlife exhibit while leaving the research functions to someone else. ${ }^{60}$

Almost simultaneously, Kenneth Chorley, an officer of Jackson Hole Preserve, Inc. and Rockefeller shared similar thoughts. They discussed the possibility of separating the animal exhibition and research functions, anticipating that Osborn and Simon would assume the management of the Research Station. However, they overlooked any possible interest that the GFC might have in taking over the animal display and instead had planned to approach the NPS. That changed on July 16 th when Senator Hunt contacted Chorley and suggested that the GFC, not the NPS, assume control of the exhibit. Almost immediately, Chorley contacted Rockefeller to share the idea presented by the Senator. It seemed the perfect solution, for Rockefeller not only questioned the interest of the NPS but also feared that if the NPS did take over the wildlife display "they would go about it in a half-hearted way, and it would finally just peter out." 61

\footnotetext{
59 JHRS Policy Statement, Box 18, Folder 15, Blair Papers.

${ }^{60}$ Miller to Hunt, July 12, 1951 and Hunt to Miller, July 16, 1951, Box 22, Folder 32, Hunt Papers.

${ }^{61}$ Chorley to Fabian, July 17, 1951, Box 4, Series

4, Folder 1, RG5 GTNP.

${ }^{62}$ Bagley to All Commissioners, August 28, 1951, Box 18, Folder 16, Blair Papers.
}

The proposal was discussed several weeks later during the August meeting of the JHWP Board of Directors. The idea received wide approval. Rockefeller requested the drafting of a letter to the GFC making a formal inquiry regarding its interest level and what conditions might apply. ${ }^{62}$ Miller committed himself to convincing the Commission members of the benefits of the plan, but both he and Hunt anticipated a challenge from Bagley. Known to be fiscally conservative, getting Bagley to approve the allocation of the necessary funds for the undertaking could have been Hunt's biggest hurdle. ${ }^{63}$

An indirect answer to the question of the acquisition of the animal display of the JHWP by the GFC came on January 3, 1952. On that day the Commission voted to discontinue its financial support, minimal as it had been compared to that of Rockefeller and the NYZS, of the JHWP. John Sherrin, president of the Commission, gave no explanation in his notification of the decision to Rockefeller. But there had been a series of minor conflicts between the GFC and management of the Park that had begun in 1948. When their concerns fell on deaf ears and improvements were not made, the commissioners lost interest in the project. Certainly politics also played a role. Everyone knew of Senator Hunt's support of the Park and of his desire for the GFC to assume responsibility for it. But the commissioners, appointees of the State's current governor and a political foe of Hunt, Frank Barrett, refused to support anything endorsed by Hunt. As long as Gov. Barrett remained in office, and their suggestions and concerns continued to be ignored, the GFC would not approve additional funding for or acquisition of the wildlife exhibit. $^{64}$

A review of Simon's reports to the Board during 1951 and 1952 indicates that the Wildlife Park and the Research Station continued normal operations during this period of uncertainty. The reports contained information about the animals-their condition, the winter feeding program, the number of calves born each spring, the number of animals transferred to other facilities. They explained construction projects, provided Information Center sales figures, reported annual visitation numbers, and

\footnotetext{
${ }^{63}$ Hunt to Miller, July 19, 1951 and Miller to Hunt, July 25, 9151, Box 22, Folder 32, Hunt Papers.

${ }^{64}$ Minutes: Wyoming GFC, January 3, 1952, p. 448, MA124, Roll 56-33-62, rr 10, dn 1.3, Game and Fish Department, Wyoming State Archive; Simon to Osborn, February 18, 1952 and Osborn to Simon, July 1, 1952, Box 4, Series, 4, Folder 3, RG5 GTNP; Fabian to Chorley, August 28, 1952, Box 5, Series, 14, Folder 2, RG5 GTNP.
} 
described any unusual events. The late spring and early summer reports often told of how severe the preceding winter weather and snowfall had been and gave information regarding the studies to be conducted at the Research Station during the upcoming summer and the awarding of grants. Simon also proudly reported on the publication of any reports that resulted from studies conducted at the Research Station. Either Simon and his staff did not know about the discussions to separate the Wildlife Park from the Research Station or they felt that the situation was out of their hands and went about their work, business as usual.

If Simon really was uninformed, that situation changed in early July, 1952 when he received a confidential letter from Osborn. As president of the NYZS, Osborn worked closely with Simon regarding the activities of the Research Station. Following the decision of the GFC at the beginning of the year to discontinue its financial support and refusal to take control of the game display, Rockefeller began negotiating in earnest with the NPS. By the end of June they had agreed upon a plan whereby the NPS would fund and continue to operate the Wildlife Park and the NYZS would retain control of the Research Station with Simon continuing as its director. Some of the details still had to be negotiated but Osborn anticipated the transfer to occur before the end of the year. ${ }^{65}$

Osborn's timetable proved accurate. In preparation for the transfer, the Jackson Hole Research Station administratively separated from the JHWP in August. Negotiations then concentrated on the division of non-real property. Certain buildings, fixtures, equipment and other assets were assigned to the Research Station. The federal government took possession of the balance of the property needed for the continued operation of the wildlife exhibit through an Instrument of Transfer. At the same time, the JHP formally gave control of the Research Station to the NYZS. The filing of the Notice of Dissolution, stating that "Jackson Hole Wildlife Park, a Wyoming corporation will be dissolved forever," occurred on October 30, 1952. ${ }^{66}$

The legal entity of the JHWP dissolved but the wildlife exhibit continued, at least for a while. Even though the State retained ownership of the

${ }^{65}$ Osborn to Simon, July 1, 1952, Box 4, Series, 4, Folder 3, RG5 GTNP.

66 Historical Chronology, NPS, www.nps.gov/history/history/online books/npsg/research station/chronology.htm; Instrument of Transfer, October 15, 1952, Box 4, Series 10, Folder 5, RG5 GTNP; Notice of animals, the GFC allowed them to remain on the property under the care of the NPS. In addition, Commissioner Bagley generously offered the Commission's support and assistance to GTNP Superintendent Freeland in operation of the exhibit and any expansion to it that the NPS might undertake in the future. Expansion never happened. And it was not long before Rockefeller's concern about the commitment of the NPS to the exhibit became a reality.

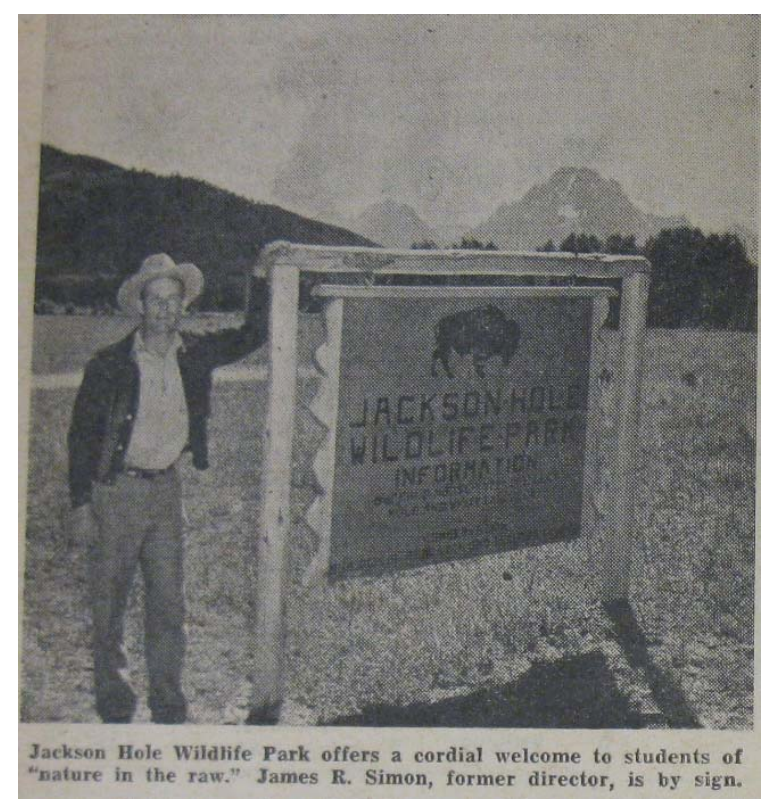

Figure 9. Jim Simon, director of the JHWP, 1946$52 .{ }^{67}$

Arthur Demaray succeeded Director Drury the previous year but he had no intention of reversing the policy against artificial confinement of wild animals. Wildlife management practices in the national parks now fell in line with the beliefs of Olaus Murie and other like minded conservationists. A park ranger, Karl Allan, oversaw the exhibit and cared for the animals for a number of years but over time interest in maintaining the exhibit waned. By the late 1950s the NPS turned its attention to the Mission 66 project, an effort to expand facilities in preparation for the $50^{\text {th }}$ anniversary of the founding of the NPS. Construction of a new visitor center near Park Headquarters in Moose became the major priority for GTNP. In comparison, the wildlife exhibit of the former JHWP was an afterthought. ${ }^{68}$

Dissolution, October 30, 1952, Box 5, Series 14, Folder 1 RG5 GTNP..

${ }^{67}$ Photo taken from an article by Carl E. Hayden printed in the Salt Lake Times Home Magazine, November 14, 1954, Series 1, Box 9, Allan Papers.

${ }^{68}$ Biography, Series 1, Box 3, Allan Papers, AHC. 
In 1968, some of the remaining bison broke through a portion of deteriorating fencing, escaping their artificial confines. The descendants of those renegade bison now thrive on their own as the living legacy of the experiment to bridge tourism and conservation. Today's tourists are equally enthralled by the bison, elk, moose, and other animals found in GTNP. They pull off the road to look in wonder and take photographs just as tourists did at the JHWP decades ago.

The controversial wildlife exhibit officially closed in 1972. Conservation research continues at the University of Wyoming-National Park Service Research Center located at the AMK Ranch on Jackson Lake. The NYZS is no longer involved.

\section{$\downarrow$ ACKNOWLEDGEMENTS}

I would like to express my sincere gratitude to the staff members at several institutions who assisted me with my research for this project. They include the American Heritage Center at the University of Wyoming in Laramie, the Wyoming State Archives in Cheyenne, the National Archives at Denver, the Jackson Hole Historical Society, and the Rockefeller Archive Center in Sleepy Hollow, New York. I am also grateful for the opportunity of staying at the AMK Ranch which provided me with access to the former grounds of the Jackson Hole Wildlife Park.

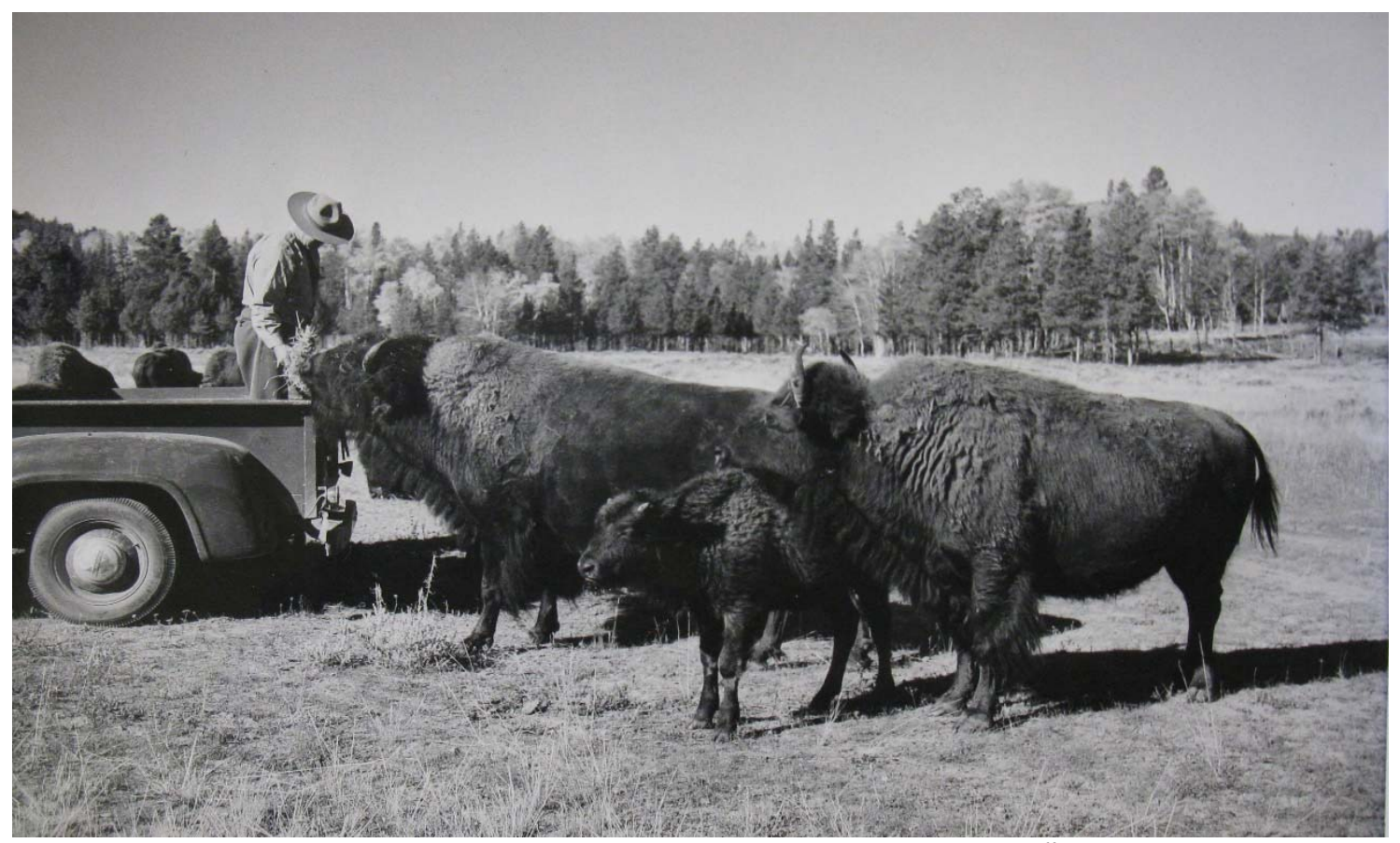

Figure 6. Park Ranger Karl Allan feeding JHWP bison, c. 1951-55. ${ }^{69}$

${ }^{69}$ Photograph, Series 2, Box 7, Karl Allan Papers (hereafter referred to as the Allan Papers), AHC. 


\section{BIBLIOGRAPHY}

\section{ARCHIVE COLLECTIONS}

Grand Teton National Park Historic Records. Moose, Wyoming. Jackson Hole Wildlife Park. Collection RG 5.

National Archives and Records Administration. Broomfield, Colorado.

NPS: Grand Teton National Monument. Collection 8NS-079-94-146.

Rockefeller Archive Center. Sleepy Hollow, New York. Grand Teton Lodge Company Records. Kenneth Chorley Papers.

University of Wyoming American Heritage Center. Laramie, Wyoming:

Karl C. Allan Papers, 1892-1979. Collection 7636.

Neal Blair Papers. Collection 10483.

Kenneth L. Diem Papers, 1876-2000. Collection 40007.

Lester C. Hunt Papers, 1889-1954. Collection 270.

Richard Winger Papers, 1913-1964. Collection 11580.

Wyoming State Archives. Cheyenne, WY. Department of Game and Fish. Collection RG 0040.

\section{$\downarrow \quad$ TOURIST PAMPHLET}

Wonderful Wyoming, Casper: Wyoming Commerce and Industry Commission, 1947-49.

Wonderful Wyoming, Casper: Wyoming Commerce and Industry Commission, 1951.

\section{SECONDARY SOURCES}

Books and Monographs

Biel, Alice Wondrak. 2006. Do (Not) Feed the Bears: The Fitful History of Wildlife and Tourists in Yellowstone. University Press of Kansas, Lawrence, KS.

Blair, Neal. 1987. The History of Wildlife Management in Wyoming. Wyoming Game and Fish Department, Cheyenne, WY.
Newhall, Nancy. 1957. A Contribution to the Heritage of Every American: The Conservation Activities of John D. Rockefeller, Jr. Alfred A. Knopf, New York.

Righter, Robert W. 1982. Crucible for Conservation: the Struggle for Grand Teton National Park. Colorado Associated University Press, Boulder. CO.

Sellers, Richard West. 1997. Preserving Nature in the National Parks: A HistoryYale University Press, New Haven.

Winks, Robin W. 1997. Laurance S. Rockefeller: Catalyst for Conservation. Island Press, Washington, D.C.

\section{JOURNAL ARTICLES}

Negus, Norman C. 1950. Breeding of Three-Year-Old Females in the Jackson Hole Wildlife Park Buffalo Herd. Journal of Mammology 31(4): 463.

Schenck, Marian Albright. 2007. One Day on Timbered Island: How the Rockefellers' Visits to Yellowstone Led to Grand Teton National Park. Montana: The Magazine of Western History 57(2): 22-39+93-94.

\section{$\uparrow$ ONLINE SOURCES}

Diem, Lenore. "The Research Station's Place in History." National Park Service. http://www.nps.gov/history/history/online _ b ooks/npsg/research station/index.htm (accessed February 13, 2013).

Historical Chronology, NPS, www.nps.gov/history/ history/online books/npsg/research_station/ chronology.htm (accessed February 13, 2013).

Jackson Hole Wildlife Park, National Park Service, http://www.nps.gov/grte/historyculture/jhwp .htm (accessed February 18, 2013).

Jean Théodore Delacour, Wikipedia, http://en.wikipedia.org/wiki/Jean Th\% $3 \%$ A9odore Delacour (accessed May 1, 2014).

New York Times, November 29, 1985, http://www.nytimes.com/1985/11/29/world/ dr-jean-delacour-95-leadingornithologist.html (accessed May 1, 2014).

Wildlife Management - Creating a Game Preserve, Wind Cave National Park, National Park Service,http://www.nps.gov/wica/parkmgmt wildlife-management-creating-a-gamepreserve.htm, 